\title{
INOVASI PRODUK KUE TRADISIONAL ALI AGREM MENGGUNAKAN BAHAN DASAR TEPUNG UBI UNGU
}

\author{
Adhita Dwi Septiani, Agus Sudono, Christian H.Rumayar \\ Program Studi Manajemen Industri Katering \\ Fakultas Pendidikan Ilmu Pengetahuan Sosial \\ Universitas Pendidikan Indonesia \\ adhitadwiseptiani@yahoo.co.id
}

\begin{abstract}
ABSTRAK
Penelitian ini bertujuan untuk mengetahui konsentrasi tepung ubi ungu yang terbaik dalam pembuatan Kue Tradisional Ali Agrem, sehingga produk inovasi kue Ali Agrem Tepung Ubi Ungu dapat disukai panelis dan dapat diterima konsumen.

Metode penelitian yang digunakan dalam penelitian ini adalah metode penelitian deskriptif eksperimental. Dengan mengambil populasi yaitu 15 orang panelis pencicip perorangan untuk menilai konsentrat produk terbaik dari tiga sampel di Hotel Grand Pasundan Convention Hotel, penjual kue Ali Agrem, toko SoekarnoHatta, mahasiswa/i pastry. Disebarkan kepada 50 orang konsumen untuk mengetahui daya terima konsumen. Metode pengumpulan data dilakukan dengan membagikan kuisioner kepada panelis dan konsumen. Metode analisis data yang digunakan yaitu uji hedonik Analisis Varian (ANAVA), Least Significant Difference dan pengolahan data dengan bantuan Microsoft Excel 2010.

Dari hasil penelitian yang diperoleh, Kue Ali Agrem Tepung Ubi Ungu yang mempunyai konsentrasi terbaik yaitu kue Ali Agrem yang memiliki perbandingan 1:1,5 (100 gram tepung beras dan 150 gram tepung ubi ungu).

Kata Kunci: Inovasi Produk, Ali Agrem, Bahan Dasar, Tepung Ubi Ungu

\section{PENDAHULUAN}

Negara Indonesia yang terdiri dari beribu-ribu pulau yang tersebar dari ujung Barat sampai ujung Timur.Selain itu Indonesia mempunyai beragam suku dan budaya yang beragam pula.Dari berbagai bidang yang ditekuni masyarakat Indonesia dalam dunia usahanya, bidang pariwisata merupakan salah satu bidang yang banyak ditekuni oleh masyarakat Indonesia sebagai dunia usaha atau lahan usaha mereka.

Begitu juga dengan makanan atau kue tradisional yang terdapat dan tersebar di seluruh suku dan budaya di Indonesia.Untuk tetap menjaga kelestarian dan keaslian makanan dan kue tersebut diperlukan suatu industri yang tepat untuk menjaga kelestarian makanan dan kue tradisional Indonesia.Dan juga dapat digunakan sebagai tumpuan dalam menarik minat para wisatawan, baik yang berada di dalam negeri maupun di luar negeri.

Penganekaragaman konsumsi pangan merupakan upaya untuk mewujudkan pola konsumsi pangan yang beragam, bergizi seimbang, aman dan halal, juga komposisi yang cukup guna memenuhi kebutuhan gizi untuk mendukung hidup sehat, aktif dan produktif.Penganekaragaman ini dapat menggunakan bahan jagung, umbi-
\end{abstract}


umbian sagu, dan sebagainya sebagai bahan pangan yang jumlah ketersediaannya, lalu dapat pula terus diusahakan produksinya, karena masyarakat Indonesia telah mengenalnya. Pemanfaatan bahan lokal ini dimaksudkan agar menciptakan produkproduk pangan bercita rasa lokal tampilan modern (be modern with local taste, motto IFOODEX 2009, Fateta IPB Bogor).

Konstribusi kuliner terhadap sektor pariwisata sangat berpengaruh, karena semakin banyaknya inovasi produk kuliner yang tercipta dari hasil kreasi modifikasi makanan.Ide dan kreativitas yang muncul memberikan sentuhan yang berbeda untuk menciptakan suatu produk olahan makanan yang memiliki ciri khas tersendiri dengan cita rasa yang menggugah selera.

Inovasi produk makanan berbahan dasar lokal saat ini kurang begitu berkembang, karena kurangnya perhatian dalam membudidayakan dan pengetahuan terhadap hasil pangan lokal.Banyak potensi produk hasil bumi lokal untuk diolah menjadi makanan berkelas, seperti halnya umbi-umbian.

Ubi jalar ungu biasanya dipandang sebagai makanan yang kampungan atau ndeso.Walaupun makanan ndeso dan kampungan banyak manfaat kesehatanyang dapat diperoleh dari ubi ini, bahkan sangat jauh dari makanan modern sekarang ini (fast food).Ubi jalar ungu mengandung lisin, $\mathrm{Cu}, \mathrm{Mg}, \mathrm{K}, \mathrm{Zn}$ rata-rata 20\%.Dia juga merupakan sumber karbohidrat dan sumber kalori yang cukup tinggi. Ditambah dengan sumber vitamin dan mineral, vitamin yang terkandung dalam ubi jalar antara lain vitamin $\mathrm{A}$, vitamin $\mathrm{C}$, thiamin (vitamin B1), dan riboflavin. Sedangkan mineral dalam ubi jalar diantaranya adalah zat besi $(\mathrm{Fe})$, fosfor $(\mathrm{P})$, dan kalsium $(\mathrm{Ca})$.

Dapat dijelaskan bahwa tepung ubi ungu memiliki keunggulan dalam kandungan gizi, yaitu serat kasar, pati, gula, beta karoten, dan amilosa. Sehingga dapat disimpulkan tepung ubi ungu bisa dijadikan sebagai alternatif penggantian tepung beras dalam pembuatan ali agrem. Selain itu, dengan menggunakan tepung ubi ungu ini sebagai salah satu upaya untuk mengurangi konsumsi terigu yang semakin meningkat.

\section{TUJUAN PENELITIAN}

1. Untuk mengetahui formula resep pengolahan kue Ali Agrem dengan tepung ubi jalar ungu sebagai bahan utama.

2. Untuk mengetahui dan mengidentifikasi hasil dari uji daya tahan simpan terhadap kue Ali Agrem dengan tepung ubi jalar ungu sebagai bahan utama.

3. Untuk menganalisis dan mengetahui potensi dan manfaat

4. yang didapat setelah inovasi kue Ali Agrem dilakukan.

5. Untuk mengetahui respon dari daya terima konsumen terhadap kue Ali Agrem dengan tepung ubi jalar ungu sebagai bahan utama.

\section{METODE PENELITIAN}

Metode penelitian yang digunakan dalam penelitian ini adalah metode deskriptif eksperimental.Alasan pemilihan metode ini didasarkan pada pertimbangan dari tujuan penelitian itu sendiri yaitu untuk menggambarkan mengenai bagaimana pengaruh penggantian tepung ubi ungu terhadap kualitas produk kue Ali Agrem.

\section{OPERASIONAL VARIABEL}




\begin{tabular}{|c|c|c|c|c|}
\hline Variabel & Konsep Teoritis & $\begin{array}{l}\text { Konsep } \\
\text { Empiris }\end{array}$ & $\begin{array}{l}\text { Konsep } \\
\text { Analitik }\end{array}$ & Skala \\
\hline $\begin{array}{l}\text { Inovasi } \\
\text { Produk }\end{array}$ & $\begin{array}{l}\text { Standar kualitas suatu } \\
\text { mutu makanan. Hal-hal } \\
\text { yang harus diperhatikan } \\
\text { adalah : flavour (rasa/ } \\
\text { bau), consistency } \\
\text { (kemantapan/ } \\
\text { ketetapan), texture/ } \\
\text { form/ shape (susunan/ } \\
\text { bentuk/ potongan), } \\
\text { nutritional content } \\
\text { (kandungan gizi), visual } \\
\text { appeal (daya penarik } \\
\text { lewat ketajaman mata), } \\
\text { aromatic appeal (daya } \\
\text { penarik lewat bau } \\
\text { harum), temperature } \\
\text { (panas/suhu). (marsum, } \\
\text { 2005: 159) }\end{array}$ & $\begin{array}{l}\text { Mutu } \\
\text { makanan } \\
\text { harus } \\
\text { sangat } \\
\text { diperhatika } \\
\mathrm{n} \quad \text { dilihat } \\
\text { dari } \\
\text { persepsi } \\
\text { kualitas } \\
\text { produk } \\
\text { pada } \\
\text { mkanan itu } \\
\text { sendiri }\end{array}$ & $\begin{array}{l}\text { Data diperoleh } \\
\text { dengan uji } \\
\text { deskripsi dan uji } \\
\text { hedonik : } \\
\text { - Rasa } \\
\text { - Kemantapan } \\
\text { (formula resep) } \\
\text { - Bentuk } \\
\text { - Tekstur } \\
\text { - Daya penarik } \\
\text { lewat ketajaman } \\
\text { mata (dilihat dari } \\
\text { warna) } \\
\text { - Aroma } \\
\text { - Temperature } \\
\text { penyajian }\end{array}$ & Ordinal \\
\hline $\begin{array}{c}\text { Daya } \\
\text { Terima } \\
\text { Konsumen }\end{array}$ & $\begin{array}{l}\text { Daya terimamenyangkut } \\
\text { penilaian seseorang } \\
\text { akan suatu sifat atau } \\
\text { kualitas suatu bahan } \\
\text { yang menyebabkan } \\
\text { orang menyenangi. } \\
\text { Kesan } \\
\text { berhubungan dengan } \\
\text { kesukaan ang } \\
\text { tanggapan senang atau } \\
\text { tidaknya terhadap sifat } \\
\text { sensorik atau kualitas } \\
\text { yang dinilai (Soekarto, } \\
\text { 1985:77). }\end{array}$ & $\begin{array}{l}\text { Penilaian } \\
\text { suka atau } \\
\text { tidak suka } \\
\text { dapat } \\
\text { dianalisis } \\
\text { dengan : } \\
\text { - Rasa } \\
\text { - Bentuk } \\
\text { - Tekstur } \\
\text { - Warna } \\
\text { - Aroma }\end{array}$ & $\begin{array}{l}\text { Hasil dari } \\
\text { penilaian suka atau } \\
\text { tidak suka bisa } \\
\text { mengetahui }\end{array}$ & Ordinal \\
\hline
\end{tabular}

\section{POPULASI}

Populasi yang digunakan dalam pelelitian ini tidak menggunakan sampling tetapi populasi yang didapat diteliti semua. Banyaknya populasi yang akan di uji kesukaannya (uji hedonik) pada produk kue Ali Agrem tepung ubi ungu sebanyak 15 orang panelis terlatih yang mempunyai kepekaan dalam bidang pastry. Tahapan berikutnya dilakukan akan dilakukan uji perbandingan produk konsentrat terbaik dengan produk kontrol yang di ujikan kepada 15 orang panelis terlatih. Terakhir adalah uji daya terima konsumen dan banyaknya populasi yaitu sebanyak 50 orang panel konsumen. 


\section{TEKNIK ANALISIS DATA}

Teknik mengolah data dengan menggunakan rancangan acak kelompok sebagai berikut:

$\mathrm{FK}=\frac{\left(\sum X\right)^{2}}{T * r}$

JK (P) $=\frac{(x)^{2}+\cdots+(x)^{2}}{r}-$ Faktor Koreksi

$\mathrm{JK}(\mathrm{S}) \quad=\frac{(y)^{2}+\cdots+(y)^{2}}{T}$ - Faktor Koreksi

$\mathrm{JK}(\mathrm{T})=\left(S^{2}+\cdots+S^{2}\right)$ - Faktor Koreksi

JK $(\mathrm{G})=\mathrm{JK}$ Total $-\mathrm{JK}$ Panelis $-\mathrm{JK}$ Sampel

Dimana hasil uji hedonik kemudian dilakukan analisis varian (ANAVA) selanjutnya dilakukan uji Least Significant Difference (LSD) dengan selang kepercayaan 95\% untuk mengetahui pengaruh antar perlakuan.

\section{HASIL dan PEMBAHASAN}

\section{Formula resep pengolahan inovasi produk kue Ali Agrem}

Dalam eksperimen yang telah dilakukan peneliti, ada tiga formula resep yang diujikan kepada setiap panelis. Dari ketiga formula resep tersebut, formula resep dua $\left(\mathrm{AA}_{2}\right)$ dengan perbandingan tepung beras dan tepung ubi ungu 1:1,5 terpilih sebagai formula yang paling banyak disukai.

\section{Uji daya tahan simpan inovasi produk kue Ali Agrem}

Berdasarkan pengamatan, formula resep satu $\left(\mathrm{AA}_{1}\right)$ mempunyai daya tahan simpan yang sama dengan produk kontrol (Ali Agrem asli), sedangkan formula resep dua dan tiga mempunyai daya tahan simpan yang lebih rendah dibandingkan dengan produk kontrol (Ali Agrem asli).

\section{Potensi dan manfaat setelah inovasi}

Dari segi value inovasi produk kue Ali Agrem memiliki keunggulan dalam kandungan gizi dibandingkan dengan produk kontrol.Produk inovasi memiliki kandungan gizi beta karoten yang cukup banyak.

\section{Daya terima konsumen terhadap produk inovasi kue Ali Agrem}

Daya terima konsumen terhadap produk inovasi cukup baik, yaitu 30 orang dari 50 orang konsumen menyukai produk inovasi kue Ali Agrem tersebut.Tekstur yang didapat dari $\mathrm{AA}_{2}$ tidak terlalu keras dan tidak terlalu empuk.

\section{SIMPULAN}

1. Proses pengolahan kue Ali Agrem dengan tepung ubi ungu sebagai bahan utama dimulai dengan membuat tepung ubi ungu terlebih dahulu dari ubi jalar ungu yang dilolah melalui proses penepungan yang dilakukan sendiri oleh penulis. Setelah itu dilakukan beberapa proses eksperimen yang dilakukan penulis untuk menemukan konsentrasi terbaik yang akan dijadikan formula tetap inovasi produk Ali Agrem. Dari beberapa konsentrasi yang dilakukan, terpilih satu konsentrasi terbaik yang dipilih oleh panelis terlatih. Formulanya yaitu sebesar 
150 gram tepung ubi ungu, dan 100 gram tepung beras (bahan dasar asli dari kue Ali Agrem). Tepung ubi ungu dan tepung beras ini dicampurkan dengan gula merah yang telah dicairkan bersama 150-160 ml air dan gula pasir. Setelah adonan ini tercampur maka adonan didiamkan sebentar, barulah adonan tersebut digoreng dalam minyak goreng yang telah dipanaskan terlebih dahulu.

2. Berdasarkan hasil dari uji daya tahan simpan yang dilakukan oleh penulis terhadap kue Ali Agrem dengan tepung ubi ungu sebagai bahan utama, inovasi dari kue Ali Agrem mempunyai daya tahan simpan yang lebih cepat basi / tidak layak untuk dikonsumsi bila dibandingkan dengan produk asli kue Ali Agrem.

3. Potensi yang didapatkan setelah inovasi dilakukan, yaitu value dari produk inovasi kue Ali Agremlebih baik dikarenakan banyak mengandung kandungan gizi yang didapatkan dari tepung ubi ungu yaitu mengandung beta karoten yang berguna bagi tubuh. Dari segi ekonomi, inovasi produk kue Ali Agrem ini memang agak mahal dibandingkan dengan produk kue Ali Agrem asli. Oleh karena itu, produk inovasi ini sasaran pasar yang dituju adalah kalangan menengah ke atas.

4. Respon daya terima konsumen terhadap inovasi kue Ali Agrem dengan tepung ubi ungu sebagai bahan utama cukup baik. Sekitar 30 orang menyukai rasa ubi ungu yang sudah tidak asing lagi pada lidah konsumen, dan tekstur dari inovasi produk ini lebih lembut dibandingkan dengan produk aslinya dengan bahan dasar hanya tepung beras saja. Walaupun beberapa orang tetap menyukai produk aslinya, namun produk inovasi dapat dikatakan berhasil karena hampir seluruh konsumen menyukai produk inovasi tersebut.

\section{DAFTAR PUSTAKA}

Dinas Pariwisata dan Kebudayaan Provinsi Jawa Barat. (2011, Desember 12). Retrieved November 20, 2013, from Dinas Pariwisata dan Kebudayaan Provinsi Jawa Barat: www.diparbud.jabarprov.go.id

Gardjito, M., Djuwardi, A., \& Harmayani, E. (2013). Komoditas Ubi Jalar. In Pangan Nusantara: Karakteristik dan Prospek untuk Percepatan Diversifikasi Pangan. Jakarta: Kencana Prenada Media Group.

Jiyo. (2013, Juni 21). Camilan Khas Sunda yang Bikin Nagih. Retrieved November 20, 2013, from Open Rice: www.openrice.com

Mahmud, M., Hermana, Zulfianto, N. A., Apriyantono, R.R., Ngadiarti, S., Hartati, B.,Bernadus, Tinexcelly. (2009). Tabel Komposisi Pangan Indonesia. Jakarta: PT. Elex Media Komputindo

Richana, N. (2013). Menggali Potensi Ubi Kayu dan Ubi Jalar. Bandung: Nuansa Cendekia.

Soekarto, Soewarno T. (1985). Penilaian Organoleptik untuk Industri Pangan dan Hasi Pertanian. Bogor: Bhratara Karya Aksara

WA, Marsum. (2005). Restoran dan Segala Permasalahannya. Yogyakarta: ANDI. 